\title{
Nitrogen removal by floating constructed wetland: Decontamination of the Buriganga River
}

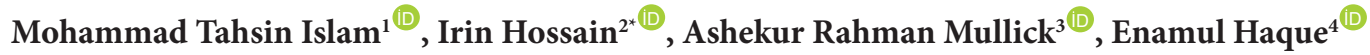 \\ ${ }^{1}$ Resident Engineer (Civil), Gerico France, Paris, France \\ ${ }^{2}$ Department of Occupational and Environmental Health, National Institute of Preventive and Social Medicine (NIPSOM), Dhaka, \\ Bangladesh \\ ${ }^{3}$ National Institute of Preventive and Social Medicine (NIPSOM), Dhaka, Bangladesh \\ ${ }^{4}$ Jamil Iqbal Limited, Dhaka, Bangladesh
}

\begin{abstract}
Background: Buriganga is considered as one of the most important river in the country. But, its water quality has changed dramatically, which is responsible for creating unfavorable conditions for aquatic life. The main aim of this study was to investigate the removal capacity of pollutants mainly nitrogen present in the Buriganga river as the most polluted rivers in Bangladesh, by floating constructed wetland. Methods: This study was conducted under constant and variable shock loadings in two phases, namely 'Phase I' and 'Phase II' during 11 and 10 weeks, respectively, in which about $180 \mathrm{~L}$ of raw water was dosed into the tank containing a floating mat, and pollutant concentrations in the river water influent from the system were tested over a period of 21 weeks.

Results: Floating treatment wetland (FTW) could sustain and remove about $31.25 \%$ and $19.23 \%$ of ammonia in the 9th and 10th weeks of Phase I, respectively, and $40.63 \%$ and $56.12 \%$ in the 17 th and 18 th weeks of Phase II, respectively. At first, ammonia was converted to ammonium, then, to nitrite, and finally, to nitrate. As the rhizosphere was denser and the biofilm was thicker in this study, so nitrogen removal efficiency during the application of shock loading in the 17th and 18th weeks of Phase II was considerable. The removal percentage of nitrite was 76.12 and $80 \%$, respectively. In regular dosing of raw water in the 11th and 19th weeks in Phase I and Phase II, respectively, the total nitrate removal efficiencies from influent were 31.91 and $43.33 \%$, respectively.

Conclusion: As water resources are limited, so improvement of water quality of the polluted Buriganga river would act as an important source of reusable water.

Keywords: Nitrogen, Nitrites, Nitrates, Ammonium compounds, Water quality, Wetlands, Bangladesh Citation: Islam MT, Hossain I, Mullick AR, Haque E. Nitrogen removal by floating constructed wetland: Decontamination of the Buriganga River. Environmental Health Engineering and Management Journal 2020; 7(3): 203-208. doi: 10.34172/EHEM.2020.23.
\end{abstract}

Article History:

Received: 1 June 2020

Accepted: 29 July 2020

ePublished: 9 September 2020

\section{Introduction}

The Buriganga river system is located in the southern part of the north central region of Bangladesh, passing through west and south of Dhaka, the capital of Bangladesh. Experts identified nine industrial areas in and around the capital city as the primary sources of river pollution: Tongi, Tejgaon, Hazaribagh, Tarabo, Narayangonj, Savar, Gazipur, Dhaka Export Processing Zone, and Ghorashal (1). The river receives wastewater from numerous number of sources along its way, which discharge industrial effluents, municipal sewage, household waste, clinical waste, and oils. According to irrigation, fishing and transportation, Buriganga is considered as one of the most important rivers in the country. But, its water quality has changed dramatically, which is responsible for creating unfavorable conditions for aquatic life. Millions of liters of sewage, domestic waste, industrial and agricultural effluents act as toxic wastes and cause water pollution. Among different industries, textile industries account for discharge of nearly 56 million tons of waste and 0.5 million tons of sludge (2). Nearly 4 million people were exposed to the consequences of water pollution every day (3). The odor of the river varies from season to season. In dry season, it was found bad in some places whereas the condition was found a bit improved in wet season $(4,5)$. Floating treatment wetland (FTW) is an innovative, new type of constructed wetland system, which was consistent with the mechanism of surface flow wetland. Therefore, 
it could be considered as a water treatment technology which is consisted of a floating, porous platform on which plants were established for the purpose of remediating any number of water quality or habitat issues. Both plants and bacteria that live on the extensive network of roots served to bind and remove contaminants and nutrients, and therefore, leaving the water cleaner. These wetlands effectively worked on various wastewater parameters such as biochemical oxygen demand, chemical oxygen demand, Total suspended solids, dissolved oxygen, phosphate, nitrogen, turbidity, $\mathrm{pH}$, alkalinity, redox potential, and also, effectively reduced the amount of Escherichia coli and Salmonella $(6,7)$.

In the USA, the characteristics of nitrogen $(\mathrm{N})$ and phosphorus removal were studied during the 2-year operation of a free water surface flow wetland of $900 \mathrm{~m}^{2}$ with hydraulic loading. The main source of water as an urban watercourse which was contaminated with urban and industrial wastewater. Since the main purpose was to assess water treatment of contaminated water for use of general purpose, therefore, attention was focused on the removal of contaminants and harmful chemicals by harvesting plants (Phragmites australis and Typha orientalis) at the end of each growing season (8). The prospect of these types of wetlands in Bangladesh is enormous; they are easy to construct, require very low maintenance, and their fabrication is very cost-effective. Emergent plants act as artificial mats, and ultimately, form wetland basins or cells. This is not similar to the treatment using floating-leaved plants such as Eichhornia crassipes (water hyacinth) (9), Pistia stratiotes (water lettuce), Lemna spp. (duckweed) or Azolla spp. (water fern) or where natural floating islands had been established (10). This system is formally known as "floating treatment wetlands" or "constructed floating wetlands" or "floating mat constructed wetlands". 'Effluent' is considered as the water that is being treated at any stage within the wetland and 'inflow' is considered as the water entering the wetland through effluent, and 'outflow' is considered as effluent leaving the wetland. Basins where there was open water but no islands, were known as free water surface wetlands (10).

A cross-sectional study in China showed that in a successive sequence system of the floating-bed constructed wetland (FBCW), horizontal subsurface flow constructed wetland (HSFCW) and surface flow constructed wetland (SFCW) were constructed for the inner-city tributary treatment in the cold regions of North China. The study area was Yitong River, in which the designed capacity and the hydraulic loading of the system was $100 \mathrm{~m}^{3} / \mathrm{d}$ and $0.10 \mathrm{~m}^{3} /$ $\mathrm{m}^{2} \mathrm{~d}$, respectively. The hydraulic retention time was about 72 hours. It was conducted between April and October 2016. The results showed that the multiple wetland ecosystem could successfully remove industrial chemical waste particles like chemical oxygen demand, ammonia nitrogen, total nitrogen, total phosphate, and suspended solids at average removal rates of $74.79 \%, 80.90 \%, 71.12 \%$, $78.44 \%$, and $91.90 \%$, respectively (11).

A study in Brazil showed that emergent plants removed about $3.95 \mathrm{mgP} / \mathrm{m}^{2}$ pollutants daily, which is responsible for removal of about $30.6 \%$ pollutants by artificial wetlands, while removal of the rest $69.1 \%$ pollutants are done by other means like substrates and microorganisms. The results indicate that in artificial wetlands, nitrogen rather than other pollutants was removed by other means like substrates and microorganisms (12).

\section{Materials and Methods}

In order to observe the capacity of removal efficiency of ammonia, nitrite, and nitrate by FTW under constant and variable shock loadings, the total system was organized into 4 following parts:

- Dosing and shock loading

- Configuration of floating wetland system

- Configuration of tank

- Configuration of floating mat

- Plants

- Arrangement and sampling

\section{Dosing and shock loading}

Raw river water was collected from Buriganga river located in Dhaka, Bangladesh, and dosed into the FTW system. The study was conducted in two phases, namely 'Phase I' and 'Phase II' during 11 and 10 weeks, respectively. 180 $\mathrm{L}$ of raw water was dosed into the system each day of the weeks in both phases. A shock load of 900 and $1800 \mathrm{~L}$ was dosed into the system in the first day of the 9th and 10th weeks individually and in the order that already mentioned in Phase I. Similarly, a shock load of 1260 and $2520 \mathrm{~L}$ was dosed into system in the 17th and 18th weeks in Phase II.

\section{Configuration of floating wetland system}

A rectangular concrete tank was used to replicate the plants on a large scale. A floating mat was used as a media for the growth of microbial community. The system used for this purpose was a rectangular airtight UPVC platform on which a mat was setup where a variety of plants were allowed to grow while their roots were submerged in water. In the first part, emergent plants (primarily Oriental Sword) were planted. It was constructed in such a way that could facilitate the growth of roots underwater.

\section{Configuration of tank}

The concrete tank had a rectangular shape (length $=3.60$ $\mathrm{m}$, width $=1.17 \mathrm{~m}$, height $=1.14 \mathrm{~m}$ ) with an opening which had been fitted with a pipe of 1-inch diameter. The outlet was used for collecting samples. The FTW was placed between the tank. The tank was filled initially with $20 \%$ raw water and $80 \%$ fresh water. The capacity of tank was $2500 \mathrm{~L}$. 


\section{Configuration of floating mat}

The floating mat as a primary structural element was an infrastructure of four high-performance UPVC pipes of 4-inch diameter, interconnected with four PVC angles and made airtight. The mat had a $10 \mathrm{ft}$ length $\times 3 \mathrm{ft}$ width. First, PVC platform was constructed for infrastructural and buoyant support, and then, the net was placed into the angled PVC pipe. Afterwards, the net was filled with straw. It was further filled with saturated clay soil. The tank was filled with up to $20 \%$ raw water and $80 \%$ fresh water. After mat construction, necessary plants were planted on the mat. Then, a waterlogged period of 20-25 days was provided.

\section{Plants}

Plants used in the system were collected from local water bodies and nurseries. Plants used in the systems are listed below:

Phragmites australis: It is widely found in temperate and tropical regions. It is used in constructed floating wetland where bioremediation bacterial action on the surface of roots and leaf litter removed some of the nutrients in biotransformation. It is a helophyte, especially common in alkaline habitats, which can tolerate brackish water.

Canna indica: It could be used for the treatment of industrial wastewater through constructed wetlands. It was effective for removal of high organic loads, dye and chlorinated organic compounds from paper mill wastewater. It could be also used for beautification.

Sample size, sample characteristics, and analysis methods After dosing of $180 \mathrm{~L}$ raw water in the wetland system, the effluent was collected in a high-density polyethylene bottle from the outlet of the tank. The collected samples were tested for nitrogen compounds (ammonia, nitrite, and nitrate). Raw river water was collected from Buriganga River located in Dhaka, Bangladesh, and dosed into the FTW system. The study was conducted in two phases, namely 'Phase I' and 'Phase II', during 11 and 10 weeks, respectively. The level of nitrogen compounds (ammonia, nitrite, and nitrate) was measured in the lab using water and wastewater monitoring and analysis methods (4th Edition) (13).

\section{Results}

The FTW was able to achieve high removal rates of nitrogen compounds (ammonia, nitrite, and nitrate) under constant and variable shock loadings. The total removal rates of nitrogen compounds (ammonia, nitrite, and nitrate) are shown in Table 1. The ammonia concentrations in the influent and effluent for Phase I and Phase II are shown in Table 1 and Figure 1. The nitrite concentrations in the influent in Phase I and effluent in Phase I are presented in Table 1 and Figure 2. The nitrate concentrations in the

Table 1. Weekly distribution of concentrations of nitrogen compounds in the influent and effluent flows, and removal percentage of these compounds by floating constructed wetland

\begin{tabular}{|c|c|c|c|c|c|c|c|c|c|}
\hline \multirow[b]{2}{*}{ Week } & \multicolumn{3}{|c|}{ Nitrogen (Nitrate) } & \multicolumn{3}{|l|}{ Nitrogen (Nitrite) } & \multicolumn{3}{|c|}{ Nitrogen (Ammonia) } \\
\hline & $\begin{array}{l}\text { Influent } \\
\text { (mg/L) }\end{array}$ & Effluent (mg/L) & Removal (\%) & Influent (mg/L) & Effluent (mg/L) & Removal (\%) & $\begin{array}{l}\text { Influent } \\
\text { (mg/L) }\end{array}$ & $\begin{array}{l}\text { Effluent } \\
\text { (mg/L) }\end{array}$ & Removal (\%) \\
\hline 1 & 8.1 & 7.2 & 11.11 & - & - & - & 39 & 3.64 & 90.67 \\
\hline 2 & 12.5 & 6.6 & 47.20 & - & - & - & 58.5 & 2.21 & 96.22 \\
\hline 3 & 6.5 & 25 & 0.00 & - & - & - & 17 & 8 & 52.94 \\
\hline 4 & 6.8 & 12 & 0.00 & - & - & - & 31.2 & 17.6 & 43.59 \\
\hline 5 & 9.3 & 30 & 0.00 & - & - & - & 74 & 39 & 47.30 \\
\hline 6 & 20 & 15.2 & 24.00 & - & - & - & 26 & 1.5 & 94.23 \\
\hline 7 & 13.4 & 8.2 & 38.81 & - & - & - & 26 & 5.2 & 80.00 \\
\hline 8 & 4.8 & 5.7 & 0.00 & 0.016 & 0.05 & 0.00 & 7.02 & 1.54 & 78.06 \\
\hline 9 & 7.3 & 2.9 & 60.27 & 0.016 & 0.02 & 0.00 & 2.08 & 1.43 & 31.25 \\
\hline 10 & 4.3 & 3.2 & 25.58 & 2.75 & 0.56 & 79.64 & 2.6 & 2.1 & 19.23 \\
\hline 11 & 4.7 & 3.2 & 31.91 & 0.44 & 0.04 & 90.91 & 2.86 & 0.78 & 72.73 \\
\hline 12 & 4.3 & 3 & 30.23 & 1.68 & 0.43 & 74.40 & 2.8 & 1.6 & 42.86 \\
\hline 13 & 0.53 & 0.26 & 50.94 & 1.86 & 0.42 & 77.42 & 2.38 & 0.69 & 71.01 \\
\hline 14 & 0.9 & 7 & 0.00 & 0.3 & 0.016 & 94.67 & 0.78 & 0.65 & 16.67 \\
\hline 15 & 4.2 & 2.4 & 42.86 & 0.26 & 0.07 & 73.08 & 0.26 & 0.62 & 0.00 \\
\hline 16 & 0.7 & 0.9 & 0.00 & 0.016 & 0.016 & 0.00 & 0.91 & 0.52 & 42.86 \\
\hline 17 & 0.96 & 0.59 & 38.54 & 0.067 & 0.016 & 76.12 & 1.28 & 0.76 & 40.63 \\
\hline 18 & 0.4 & 0.1 & 75.00 & 0.08 & 0.016 & 80.00 & 0.98 & 0.43 & 56.12 \\
\hline 19 & 3 & 1.7 & 43.33 & 0.09 & 0.016 & 82.22 & 0.84 & 0.58 & 30.95 \\
\hline 20 & 6.8 & 2.3 & 66.18 & 0.09 & 0.02 & 77.78 & 0.9 & 0.72 & 20.00 \\
\hline 21 & 5.4 & 2.8 & 48.15 & 0.07 & 0.016 & 77.14 & 1.08 & 0.6 & 44.44 \\
\hline
\end{tabular}




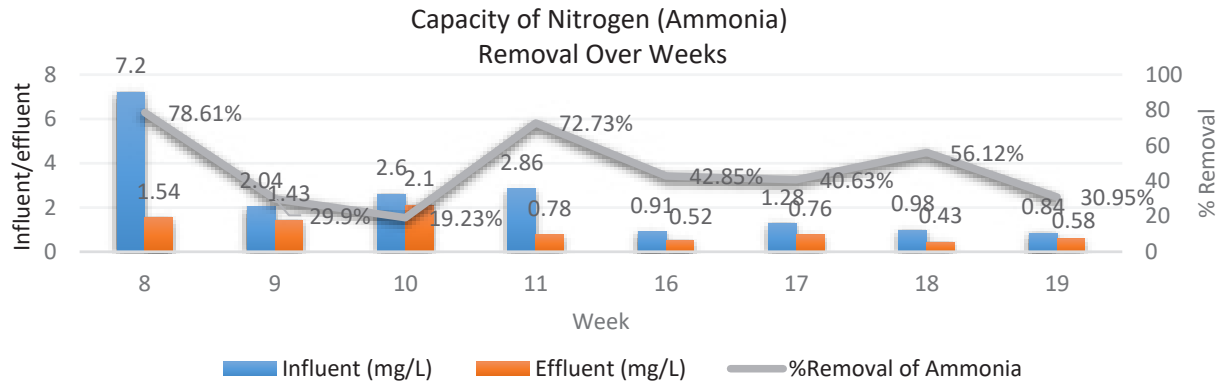

Figure 1. Nitrogen (ammonia) removal capacity over weeks.

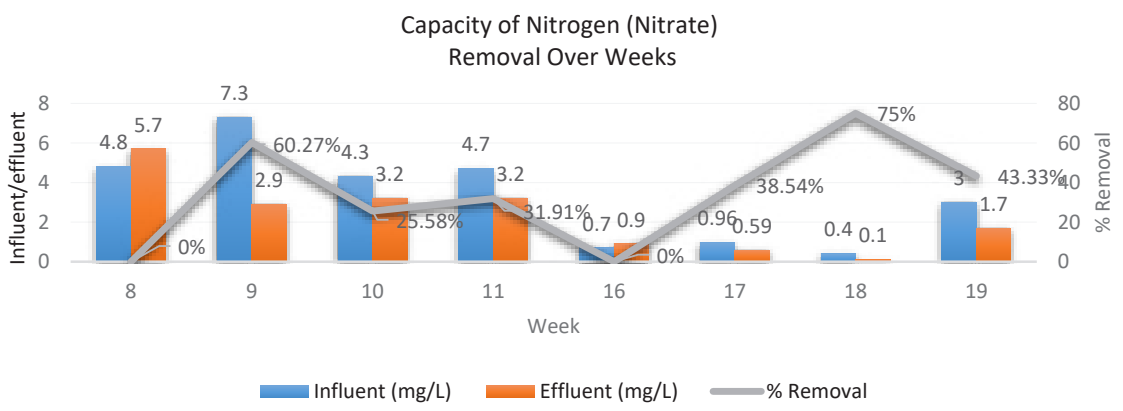

Figure 2. Nitrogen (nitrate) removal capacity over weeks.

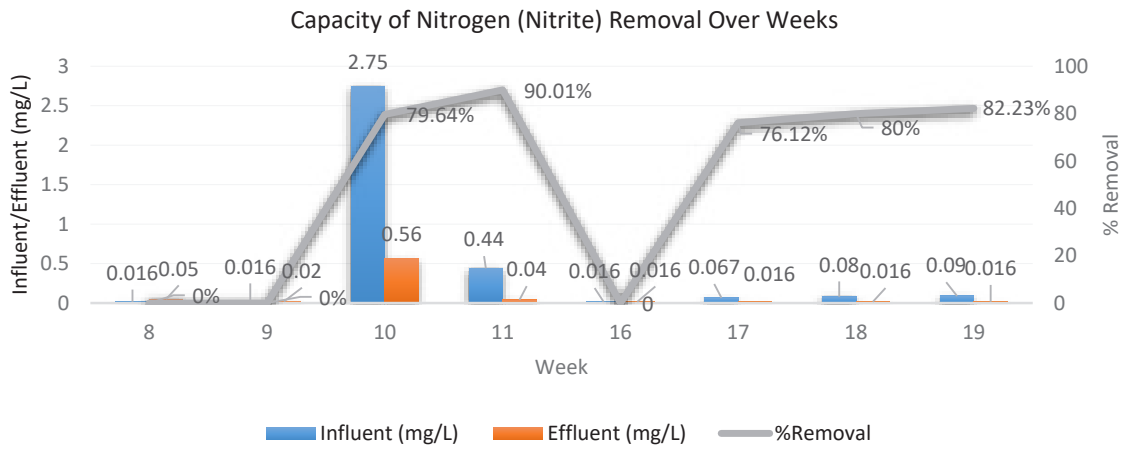

Figure 3. Nitrogen (nitrite) removal capacity over weeks.

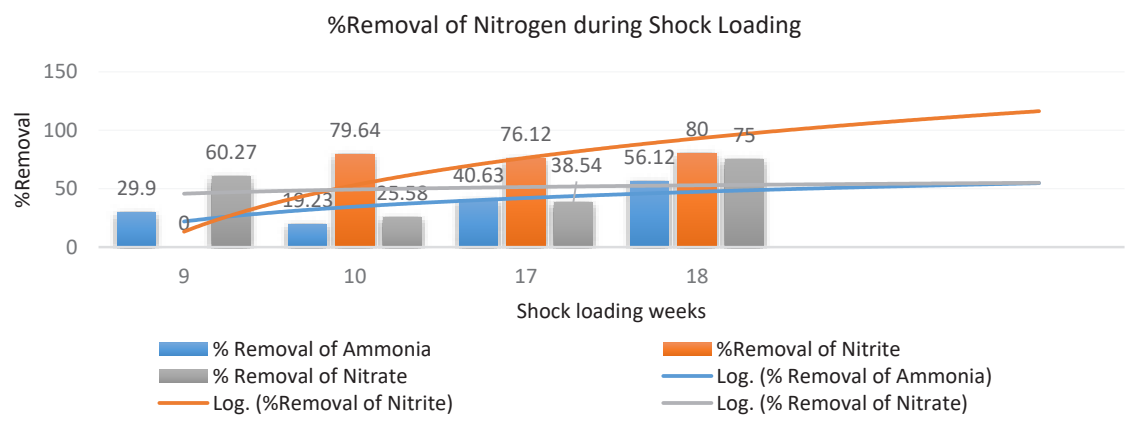

Figure 4. Removal percentage of nitrogen during shock loading. 
influent in Phase I and effluent in Phase I are shown in Table 1 and Figure 3. In regular dosing of raw water in the 8th and 11th weeks in Phase I and in the 16th and 19th weeks in Phase II, the total removal capacity of ammonia and its concentrations in the influent and effluent are described in Table 1 and Figure 4. The results of this study demonstrated the efficiency of FTWs as a low-cost and energy-efficient wastewater treatment technology for refining polluted open water bodies in Bangladesh. After gaining maturity, the system would be able to remove more than $90 \%$ of the total ammonia, nitrite, and nitrate in the influent flow.

\section{Discussion}

The physicochemical process of ammonia volatilization requires a $\mathrm{pH}$ higher than 8.0 to maintain the symmetry between gas and hydroxyl forms. $\mathrm{pH}$ values higher than 9.3 lead to the persistence of ammonia and ammonium ions in a one-to-one ratio (14).

A cross-sectional study in China showed that in a successive sequence system of the FBCW, HSFCW and SFCW were constructed for the inner-city tributary treatment in the cold regions of North China. The study area was Yitong River, in which the designed capacity and the hydraulic loading of the system was $100 \mathrm{~m}^{3} / \mathrm{d}$ and $0.10 \mathrm{~m}^{3} / \mathrm{m}^{2} \mathrm{~d}$, respectively. The hydraulic retention time was about 72 hours. Time schedule was between April and October 2016. The results showed that the multiple wetland ecosystem could successfully remove industrial chemical waste particles like chemical oxygen demand, ammonia nitrogen, total nitrogen, total phosphate, and suspended solids at average removal rates of $74.79 \%$, $80.90 \%, 71.12 \%, 78.44 \%$, and $91.90 \%$, respectively (11). In ammonification process, organic nitrogen is converted to ammonia, catabolized to amino acids, and releases energy, and has been used by some microbes for formation of new biomass (15). The formation of amino acids to ammonia depends upon some factors like temperature, $\mathrm{pH}, \mathrm{C} / \mathrm{N}$ ratio, available nutrients, and soil conditions. The majority of ammonification is done by anaerobic and obligate anaerobic mineralization (16) at an optimal temperature of $40-60^{\circ} \mathrm{C}$ and $\mathrm{pH}$ between 6.5 and 8.5 (1720). The results of this study confirmed the efficiency of FTWs as a low-cost and energy-efficient wastewater treatment technology for refining contaminated open water bodies in Bangladesh.

In 2015, a study in the USA showed that in budding season, the removal of $\mathrm{N}$ and $\mathrm{P}$ increased from $47.1 \%$ and $17.6 \%$, in the 1 st year to $52.3 \%$ and $32.4 \%$, in the 2 nd year, respectively. When they compared the wetland overall process, they found that some plants like T. orientalis and $P$. australis regenerated more vigorously and contributed more to nutrient removal (8).

Finalization of maturity system lead to the removal of almost total of ammonia, nitrite, and nitrate in the influent flow. Denitrification is the first mechanism of removing nitrogen in wastewater wetlands (18). Normally, low amounts of nitrate are found in domestic wastewater, for this reason, nitrification as well as the amount of dissolved oxygen is of great importance for proper denitrification (19). The removal efficiency of all wastewater wetlands varies between 40 and 50\% (20) depending on the treatment procedure like primary or secondary treatment $(21,22)$.

\section{Conclusion}

FTW could effectively remove nitrogen compounds (ammonia, nitrite, and nitrate) under constant and variable shock loadings. However, to reach definitive conclusions about the feasibility of Buriganga River water treatment by constructed wetland process in Bangladesh, further extended study are required. It is recommended to increase the length of system parallel to flow for providing long retention time, to use bank of Buriganga for proper application of the system, and to increase the test period to acquire adequate data for development of models.

\section{Acknowledgements}

The authors would like to gratitude all of their colleagues and other personnel of Ahsanullah University of Science and Technology (AUST) for their constructive cooperation. And special thanks to all those who helped us to perform the present study.

\section{Competing interests}

The authors declare that they have no conflicts of interests.

\section{Ethical issues}

During the study period, no human or animal faced with any types of physical violence. This study did not create any situation which might lead to environmental pollution. The authors certify that this manuscript is the original work of the authors, all data collected during the study are presented in this manuscript, and no data from the study has been or will be published separately.

\section{Authors' contributions}

MTI and EH contributed to conception and design, execution and data collection. IH and ARM contributed to data analysis and interpretation. All authors were involved in drafting the article and revising it critically for important intellectual content.

\section{References}

1. Bhowmik AK. Buriganga Pollution: Reasons \& Prospects. Dhaka: BUET; 2007.

2. Rahman MR, Rana MY. Pollution assimilation capacity of Buriganga River. J Civil Eng (Bangladesh) CE24. 1996:8595.

3. Chakraborty C, Huq M, Ahmed S, Tabassum T, Miah R. Analysis of the causes and impacts of water pollution of 
Buriganga River: A critical study. International Journal of Scientific \& Technology Research 2013; 2(9): 245-52.

4. Bhatnagar A, Devi P. Water quality guidelines for the management of pond fish culture. Int J Environ Sci 2013; 3(6): 1980-2009. doi: 10.6088/ijes.2013030600019.

5. Roy S, Banna LN, Hossain M, Rahman H. Water quality of Narai canal and Balu river of Dhaka city: An impact of industrialization. J Bangladesh Agric Univ 2014; 12(2): 285 90. doi: 10.3329/jbau.v12i2.28686.

6. Bushaw-Newton KL, Sellner KG. Harmful algal blooms. [cited 2019 Oct 12]; Available from: http://www.monae. org/documents/hab\%20noaa.pdf.

7. Mendonça E, Picado A, Cunha MA, Catarino J.Environmental management of wastewater treatment plants-the added value of the ecotoxicological approach. In: Broniewicz E. Environmental Management in Practice. IntechOpen; 2011. doi: 10.5772/18389.

8. Dzakpasu M, Wang X, Zheng Y, Ge Y, Xiong J, Zhao Y. Characteristics of nitrogen and phosphorus removal by a surface-flow constructed wetland for polluted river water treatment. Water Sci Technol 2015; 71(6): 904-12. doi: 10.2166/wst.2015.049.

9. Reddy KR, Agami M, D’Angelo EM, Tucker JC. Influence of potassium supply on growth and nutrient storage by water hyacinth. Bioresour Technol 1991; 37(1): 79-84. doi: 10.1016/0960-8524(91)90114-Y.

10. Kivaisi AK. The potential for constructed wetlands for wastewater treatment and reuse in developing countries: a review. Ecol Eng 2001; 16(4): 545-60. doi: 10.1016/S09258574(00)00113-0.

11. Bai X, Zhu X, Jiang $H$, Wang Z, He C, Sheng L, et al. Purification effect of sequential constructed wetland for the polluted water in urban river. Water 2020; 12(4): 1054. doi: 10.3390/w12041054.

12. Quan Q, Shen B, Zhang Q, Ashraf MA. Research on phosphorus removal in artificial wetlands by plants and their photosynthesis. Braz Arch Biol Technol 2016; 59: e16160506. doi: 10.1590/1678-4324-2016160506.
13. Jia G, Jing H, Hu B, Ju Z, Hui W. Water and Wastewater Monitoring and Analysis Methods. 4th ed. China: China Environmental Science Press Pub; 2002. [In Chinese].

14. Sun G, Zhu Y, Saeed T, Zhang G, Lu X. Nitrogen removal and microbial community profiles in six wetland columns receiving high ammonia load. Chem Eng J 2012; 203: 32632. doi: 10.1016/j.cej.2012.07.052.

15. Vymazal J, Brix H, Cooper PF, Haberl R, Perfler R, Laber J. Removal mechanisms and types of constructed wetlands. In: Vymazal J, Brix H, Cooper PF, Green MB, Haberl R, eds. Constructed Wetlands for wastewater Treatment in Europe. Leiden: Backhuys; 1998.

16. Vymazal J. Constructed wetlands for wastewater treatment. Water 2010; 2(3): 530-49. doi: 10.3390/w2030530.

17. Saeed T, Afrin R, Muyeed AA, Sun G. Treatment of tannery wastewater in a pilot-scale hybrid constructed wetland system in Bangladesh. Chemosphere 2012; 88(9): 1065-73. doi: 10.1016/j.chemosphere.2012.04.055.

18. EPA.Compendium of Methods for the Determination of Inorganic Compounds in Ambient Air. [cited 2019 Oct 20] Available from: https://www.epa.gov/amtic/compendiummethods-determination-inorganic-compounds-ambientair.

19. De Stefani G, Tocchetto D, Salvato M, Borin M. Performance of a floating treatment wetland for in-stream water amelioration in NE Italy. Hydrobiologia 2011; 674(1): 157-67. doi: 10.1007/s10750-011-0730-4.

20. Ye F, Li Y. Enhancement of nitrogen removal in towery hybrid constructed wetland to treat domestic wastewater for small rural communities. Ecol Eng 2009; 35(7): 104350. doi: 10.1016/j.ecoleng.2009.03.009.

21. Huda NM. Pollution Senario Capacity of Buriganga Rive, Bangladesh. 2007.

22. Van De Moortel AM, Meers E, De Pauw N, Tack FM. Effects of vegetation, season and temperature on the removal of pollutants in experimental floating treatment wetlands. Water Air Soil Pollut 2010; 212(1-4): 281-97. doi: 10.1007/ s11270-010-0342-z. 